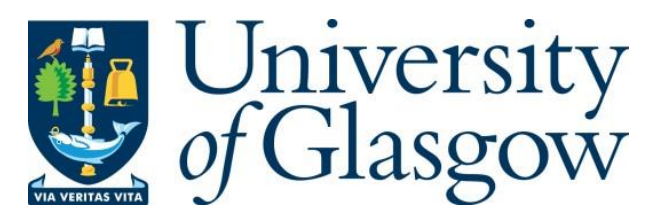

Shaw, I. G.R. (2019) Worlding austerity: the spatial violence of poverty. Environment and Planning D: Society and Space, 37(6), pp. 971-989.

(doi: $10.1177 / 0263775819857102$ )

There may be differences between this version and the published version. You are advised to consult the publisher's version if you wish to cite from it.

http://eprints.gla.ac.uk/187533/

Deposited on: 31 May 2019

Enlighten - Research publications by members of the University of Glasgow $\underline{\text { http://eprints.gla.ac.uk }}$ 


\title{
Worlding Austerity: The Spatial Violence of Poverty
}

\author{
Ian G. R. Shaw \\ School of Geographical and Earth Sciences \\ The University of Glasgow \\ Ian.Shaw.2@glasgow.ac.uk
}

\begin{abstract}
The enforced poverty of late capitalism continues to wreck our worlds. These worlds are built with a variety of social infrastructures: houses, pipes, schools, parks, libraries, and other sites of coexistence. Austerity, in turn, is spatialized and experienced across the built environment-slashing the potential of everyday worlds to provide a dignified life. By worlding austerity, I thus argue that violence against the built environment-or what I term "slow urbicide"-is simultaneously a wounding of people. My focus is on the UK, where austerity continues to inflict an insidious spatial trauma. As spatial beings, our physical and mental wellbeing is bound to the landscapes we inhabit. If these landscapes are ruined by government cutbacks-compounding the already violent production of neoliberal space-a deep world alienation and insecurity can set in. I thus reflect on the ruined social and psychological geographies of austerity. But I also offer a positive political vision: an imperative to work for the world and repair the blasted landscapes of our coexistence. The paper finishes by outlining a new right to the world: a rallying cry to flourish in more dignified spaces.
\end{abstract}

Key words: Austerity, Worlds, Housing, Urbicide, Violence, Poverty, Hannah Arendt, Martin Heidegger

\section{Blighted Worlds}

For a decade, austerity has been a defining feature of capitalist economies in Europe and North America. "Austerity," defines Matt Sparke (2017: 287), is "a common name globally for neoliberal policies of public-service cut-backs and pro-market discipline." Yet the visit of the UN's Special Rapporteur on extreme poverty to the UK still managed to create a wave of news stories. In November 2018, Phillip Alston toured some of the UK's poorest towns to assess the damage of austerity and welfare changes. He pulled no punches in his censure of the government's policies for the poorest: "British compassion for those who are suffering has been replaced by a punitive, mean-spirited, and often callous approach" (Alston, 2018: 3 ). The real function of austerity, he writes, "has not been economic but rather a commitment to achieving radical social re-engineering" (Alston, 2018: 2). The Rapporteur's 12-day visit exposed the miserable landscapes, wounded worlds, and toxic environments that millions of people inhabit. These violent geographies, "forcefully constrain, traumatize, and poison the very resources of our becoming" (Laurie and Shaw, 2018: 15).

Geographic scholarship has documented the multiple impacts of austerity. This includes research on welfare benefits (Hamnet, 2014), health and biopolitics (Bambra and Garthwaite, 2015; Pearce 2013; Sparke, 2017), governance (Newman, 2014; Slater, 2014) and "austerity urbanism" (Peck, 2012). An important strand considers how austerity is experienced in everyday life (Hall, 2018; Hitchen, 2016; Hitchen, 2019; Wilkinson and Ortega-Alcázar, 2019) - or what Alison Stenning (2018) calls austerity's psychogeographies. "By grounding austerity in lived experience," writes Esther Hitchen (2016: 102), "we are able to grasp the complexities and contradictions that are central to austerity's lived manifestations." Unlike purely capital-centric approaches, which risk masking the trauma of austerity (Pain, 2019), understanding the psychic, emotional, and social effects of austerity is vital (Hitchen and Shaw, 2019). These can materialize in spatialities and temporalities that are difficult to detect (Wilkinson and Ortega-Alcázar, 2019). As Sarah Marie Hall (2018) sums up, "New approaches to understanding everyday life in austerity are more important than ever, with ... ongoing economic and political fluxes across the world." 
The physical and mental harm of austerity is now readily apparent (British Medical Association 2016). In the UK, by 2020, welfare reform will have shortened the life of up to 200,000 people (Watkins et al., 2018). These early deaths represent what James Tyner (2016: 285) calls truncated life, or life "murdered by the material inequalities often born out of biopolitical regimes that are increasingly driven by the logic of profit." The discontents of austerity are felt deeply in bodies and minds (Sparke, 2017).

My intervention centres on how austerity damages the world. The question of austerity is always one of world: since it is within worlds that austerity is materialized and experienced (Hitchen and Shaw, 2019). Austerity is spatialized in bodies, buildings, minds, ecologies, streets-slashing the potential of worlds to provide a dignified life. Austerity is not a clearly demarcated thing, or a unified structure of causes and effects: it is the violent conditions that debilitate the worldliness of the world. As Hitchen (2019: 5) describes, "Austerity is more than an absence or presence - instead it has shape." This spatial sensitivity is not to prioritize a humanistic understanding of world (see McCormack, 2017), but to stress the interdependence between humans and their environments. My task in this paper is to show how "injustice embeds itself in the flesh and bones of the world-a world that is never above or below the human subject but threaded into its very fibres" (Laurie and Shaw, 2018: 9).

The concept of world bridges the human with its more-than-human surroundings. Worlds are the fabricated landscapes and infrastructures that support our coexistence: the houses, streets, pipes, schools, parks, subways, and other structures of life. As Judith Butler (2015: 22-23) explains, "I suggest that the "life' one has to lead is always a social life, implicating us in a larger social, economic, and infrastructural world." World has a long philosophical legacy: Martin Heidegger (2010) ${ }^{i}$ and Hannah Arendt (2013) put the question of world at the centre of their existential inquiries into human being. With reference to austerity, worlding has an immediate resonance: it enables us to see how violence against spaceagainst the built environment-is simultaneously a violence against people. The built environment is part of our subjectivity: the physical "exterior" and psychological "interior" loop together. Or as Stenning (2018) puts it, "people's everyday geographies - where they live, work, spend time, socialize, shop, etc - shape the psychical effects of austerity, and are shaped by them." Austerity and its discontents are always worlded.

Underpinning this paper is thus an existential analytic for describing human beings as spatial beings: as creatures of the world. My concern is how austerity comes to harm the social infrastructures of coexistence. While geographic research has demonstrated the spatial effects of austerity (such as the uneven geographies of health, e.g. Pearce, 2013, Bambra and Garthwaite, 2015), it is less clear how austerity is itself a spatial force: a direct "wounding" of the worlds people inhabit (Till, 2012). Here, then, we can see how worlding and wounding work together. Austerity impacts the buildings, streets, and other built ecologies of everyday life-materialising what Rachel Pain (2019) calls chronic urban trauma. As Pain (2019: 398) writes, "trauma becomes hard-wired in particular places which acquire the capacity to retraumatise, so that the city, the neighbourhood and the street, as well as individual bodies, might be understood as sites that hold chronic trauma." Consider row after row of dilapidated houses, closed libraries, poisoned water supplies, or the rats and roaches that infest social housing. These blighted buildings must be understood as blighted worlds. As Martin Coward (2006: 492) explains, "Buildings are constitutive of the worlds in which people exist."

The production of austere worlds is internal to the (uneven) capitalist production of space (Lefebvre, 1991). Yet I understand austerity's spatial violence-its distinct morphology-as a form of urbicide (Coward, 2007). Urbicide translates as violence against the city. Urbicide attacks, wounds, and breaks the fabricated worlds that bind us. Communities up and down the UK have witnessed their homes, their streets, their public services, their schools, their 
libraries, abandoned by state support. Such urbicide is a process of letting the built environment die-of slowly ruining the worldly anchors of human coexistence. Michel Foucault (2003) wrote that biopolitics is the name for the state's control over human life. This is a spatial power to manage our "environment" to ensure a "healthy" population. Yet the obverse of this power is to "let die" (Foucault, 2003: 241). This letting die recalls the violence of abandonment Friedrich Engels termed "social murder" in his tour of workingclass housing in Manchester (an eerie precursor to Phillip Alston's tour some 150 years later). The austere government, both then and now, abrogated its power to make live, and so lets die-materializing a spatial violence in the urban ecologies of everyday life (see Hitchen and Shaw, 2019). My task in this paper-and one I believe is politically urgent-is to build a theoretical platform for worlding austerity's urbicidal violence.

The paper is structured as follows. Below, I review existing work on austerity's geographies in the UK. This is followed by an examination of the concept of world and its connection to the built environment. As Jeff Malpas (2008: 32-33) argues, we always "find ourselves already given over to a certain situatedness, to a world, to a 'there." But, I ask, what exactly is there "there" of austere worlds? I then review different meanings of urbicide in the literature-from wartime destruction to economic disaster. Following Nixon (2011) and Pain (2019), I present the term "slow urbicide" to define austerity's sluggish violences. This is followed by an exploration of ruined worlds, particularly the state of housing. I then discuss the existential impacts of austerity on individuals-drawing upon themes of ontological insecurity (Giddens, 1990) and world-alienation (Arendt 2013). But the understanding of world I set out is also an opportunity. As Derek McCormack (2017: 11) argues, "engaging with worlds might also be political and ethical insofar as it is about helping us to imagine and enact different arrangements of life." There are multiple possibilities for building beyond the spatial trauma of austere worlds. Consider how communities construct thriving social centres, gardens, cooperatives, clinics, or other urban commons (Huron, 2018; Roelvink, 2016). Accordingly, the paper is as much a prognosis for more dignified worlds as it is a diagnosis for our blighted ones. I argue for the ethical imperative of working for the world: to restore and rebuild the torn fabrics of our coexistence. I finish the paper by outlining the right to the world (after Nevins, 2017): a right to appear, to coexist, and to flourish in the world.

The paper makes several contributions. First, it enhances our understanding of the complex spatialities of austerity by lodging it within the concept of world. Second, it mobilizes the literature on urbicide to consider how austerity is a violent-but slow-process of worlddestruction. Third, the paper advances scholarship on the everyday phenomenologies and psychogeographies of austerity. Fourth, it provides a unique conceptualization of the existential harm of austerity through the idea of world-alienation and what I'll later term derealization. Finally, it provides ethical and political coordinates for repairing worlds beyond the spatial violence of enforced poverty. My focus is on UK austerity, and therefore takes place within the context of an advanced (although shrinking) welfare state apparatus (Hitchen and Shaw, 2019). However, my argument is not bound to these geographies, since it provides a conceptual framework for worlding capital's many discontents.

\section{Austere Geographies}

The term austerity entered the UK political landscape after the Coalition government came to power in 2010. In an ideological sleight of hand, the burden of the massive bank bailouts under the Labour government was placed on society's most vulnerable (Clark and Newman, 2012: 300). The crises of finance capitalism were translated as political currency for a Conservative party eager to slash the welfare state. Austerity, then, was always a political decision that never made "economic sense." Austerity in the Eurozone between 2008 and 2012 typically had a negative effect on economic growth (Wolf, 2012). As popular Keynesian economists such as Paul Krugman (2015) argued, "Harsh austerity in depressed economies 
isn't necessary, and does major damage when it is imposed." Indeed, austerity has intensified the contradictions of capitalism (Harvey, 2014). So-called "quantitative easing," for example, has led to asset inflation for the wealthy and wage deflation for the poor-what Green and Lavery (2015) term regressive redistribution. Selling public assets, slashing benefits, cutting corporate tax, have all funneled capital to elites.

Austerity, then, like neoliberalism, is first and foremost a political project (Harvey, 2003)one underpinned by a greedy financialization that entrenches social inequalities. Labour's share of national income has stagnated-while capital (stocks, rent, and other financial instruments) generates obscene profits. This divergence is a source of social, economic, and political unrest, which "could lead to levels of inequality never before seen, as well as to a radically new structure of inequality" (Piketty, 2014: 23). The richest 10\% of UK households now hold $45 \%$ of all wealth. The poorest $50 \%$, by contrast, own just $8.7 \%$ (The Equality Trust, 2017), and one in three British children now live in poverty (Butler, 2017). Austerity thus exacerbates neoliberalism's inequities. The UK state is at its smallest size since records began in 1999, having made "a steady switch from a remedial to a generative force in respect of marginality, inequality and precarity" (Slater, 2014: 964)

Austerity's class war is legitimized through territorial stigmas and social pathologies (Wacquant et al., 2014). Terms like "sink estates" in the UK ghettoize the most precariousdemonizing the poor and entrenching the view that "inequality is deserved" (Tyler, 2013). Working in tandem with stigmatization is an ideology of optimism: if we just hang in there it will get better. This is what Lauren Berlant (2013) terms cruel optimism: a manufactured hope for a damaging-yet impossible-future. Indeed, unlike neoliberalism's cult-like worship of the entrepreneur, austerity demands individuals to be poor-but-resilient (Neocleous, 2013). This masculinist discourse displaces "more feminine and feminist discourses of interdependence and ethical concerns" (Newman, 2014: 3292). It is unsurprising, then, that austerity is underpinned by gendered and racial inequities. Austerity continues to impact people differentially along diverse axes of identity (Equality and Human Rights Commission, 2017; Sparke, 2017). Capitalism, of course, has always benefited spatializing gendered, sexualized, and racialized inequalities (Derickson, 2017; McKittrick 2011) - themselves bound to longer geohistories of European colonialism (McIntyre and Nast 2011, Pulido 2017; Robinson 1983).

Austerity has generated countless physical and mental health impacts (BMA, 2016; Sparke, 2017). Data collected by Watkins et al. (2018) reveals that spending cuts between 2010 and 2014 were associated with 45,000 early deaths. Underpinning these figures is a notable North-South divide in antidepressant prescriptions, food bank usage, and malnutrition (Bambra and Garthwaite, 2015). Over 2017 and 2018, there were over 1.3 million emergency food supplies given to families (The Trussell Trust, 2019). Austerity's health geographies are visible in decaying urban environments (Pain, 2019) and the rapid spread of food banks across the UK (Lambie-Mumford and Green, 2017). Other times, austerity's damage is harder to see, manifest in what Wilkinson and Ortega-Alcázar (2019: 156) describe as "forms of slow suffering." This leads to what Hitchen (2016: 105) terms "the collective moods of austerity," such as stress, anxiety, and fear. For all these reasons, Sparke (2017: 289) argues, "austerity-driven exclusion and conditionalization" is disenfranchising millions from what he terms "biological citizenship."

Urban environments concentrate the negative impacts of austerity. As Peck (2012: 629) argues, this is because cities "are 'home' to many of the preferred political targets of austerity programs - the 'undeserving' poor, minorities and marginalized populations." UK housing policy in austere times reflects what Hodkinson and Robbins (2013) call a resurrection of "class war conservatism," centered on the abrogation of social housing provision for society's most precarious (see also Harris et al., 2018). In the 1970s, local governments constructed 6.6 million homes-a third of the country's housing. Yet Margaret Thatcher's flagship 
privatization program in the 1980s-Right to Buy-gutted this stock (Hodkinson, 2012). By 2016, there were 1.18 million households on waiting lists for social housing (Department for Communities and Local Government, 2017). And in 2017, the number of social homes shrunk by 11 percent. This disinvestment in housing, the closing of services, and the slashing of welfare, is part of a wider trend: the contraction of public worlds-and with it, the psychogeographies of everyday life (Stenning, 2018). As Hitchen and Shaw (2019) write:

"The shrinking of our worlds is an insidious, barely perceptible process: the cumulative effect of dwelling in wounded and contracting ecologies-spaces in which our existence collapses into tighter and more suffocating shells."

\section{Being-There: On Worlds}

The world is not a synonym for the planet or the globe. Instead, my use of world describes the existential space, or unavoidable situatedness of being-human. We are spatial creatures who thrive within, and because of, the world. Human beings, writes Hannah Arendt (1981: 20), "are not just in the world they are of the world." To question what austerity is, then, is to ask where it is. To exist is to be in the world, to be situated, to be "there." This was Martin Heidegger's most important philosophical contribution. What we think of as the "subject," he writes, "is spatial in a primordial sense" (Heidegger, 2010: 108). To exist is to be suspended in the turbulent depths, heights, conditions, architectures, houses, and spaces of the world. We do not live as isolated monads, sealed-off bodies, or floating egos. Human being is always "being-in-the-world." From our birth to death we are spatial beings, utterly absorbed and enmeshed within the cocoons of everyday life. "Existence, we might say, is its 'there,' and in being such, it is not something separate from the there, the place, the world, in which it finds itself" (Malpas, 2008: 38). What seems obvious is no less radical: being and world are bound together.

The world is what Heidegger (2010) terms an existential space: the site of our practices and being-with-others, which constitute our unique there. The world is thus an active sphere of togetherness: a collective "happening." Or, put another way, the world worlds. That the world worlds is another way of saying that the world is not a "noun" or a "container" of activity, but itself a "verb:" a gathering of forces, things, senses, peoples and atmospheres-a turbulent site of conditions. "The 'worlding' of the world is the happening of meaning and of encounter," or "the worlding of world is also the placing, or the 'taking place,' of place" (Malpas, 2008: 40). We always find ourselves there, in a place-our existence threaded to the world and stitched to our neighbours. To find ourselves in the world means to find ourselves already immersed, given over, to other things and people. Human being is beingwith: our existence is coexistence. "Existence is with: otherwise nothing exists" (Nancy, 2000: 4).

To exist is to have a concrete there, a place in the world. And this there is always shared (ontologically). Accordingly, our existence depends less on who we are (i.e. our physical characteristics), and more on where we are-or the conditions in which we dwell. As Heidegger (2010: 116) explains, "the world is always already the one I share with others." The concept of world discloses the sociality, entanglement, and togetherness of our seemingly solipsistic existence. Human existence is worldly existence, distributed amongst other people, houses, rivers, moods, and machines. We exist because we are the world: a relational space, a being-there. Worlds are the very spaces of subjectivity, the existential infrastructures of human being.

"Through Heidegger we can see much more clearly how and why it is that human life might necessarily be social life, and why social life is always spatialised. Society is itself established and constituted through the organisation of space, and so is the sociality of being-there expressed in spatialised form, although, it is the spatiality that consists in 
the ordering of things and places given through the structure of the world." (Malpas, 2008: 61-2)

Hannah Arendt (2013) similarly describes worlds as social gatherings in spaces engineered and populated by manufactured objects. "To live together in the world means essentially that a world of things is between those who have it in common, as a table is located between those who sit around it" (Arendt, 2013: 52). Worlds are the social infrastructures-the objects and artifacts-that gather humans and nonhumans into distinct space-times. Infrastructure, adds Berlant (2016: 393), is "the lifeworld of structure. Roads, bridges, schools, food chains, finance systems, prisons, families, districts, norms all the systems that link ongoing proximity to being in a world-sustaining relation." Infrastructural life bestows our transitory biological lives with stability, security, and meaning (Arends 2013: 95-6). As Judith Butler (2015: 21) reinforces, "The dependency of human creatures on sustaining and supporting infrastructural life shows that the organization of infrastructure is intimately tied with an enduring sense of individual life: how life is endured, and with what degree of suffering, livability, or hope."

As human-beings who are necessarily beings-there, we need the there to support our biological fragility with a social infrastructure. I thus want to finish by stressing the worldliness of the built environment-the way houses and other structures of life orient our place, our strength, our vulnerability in the world. As Martin Coward (2006: 429) explains, "a building is not simply a structure erected in a pre-existing world; rather, building is an activity which generates structures that, by bringing new networks of relationships into existence, constitute the world as we know it." The built environment is a key constituent of our worlds-and not the backdrop to an aspatial humanity. Whenever housing is damaged by austerity, whenever streets are left to ruin, whenever libraries are shut, whenever infrastructure decays, it imparts an indelible wound on the human condition. The political question is not simply who we are, but where we are. And the answer, of course, is always there, thrown into worlds of dignity and violence.

\section{Urbicide: The War Against World Infrastructure}

Worlds are the bricks and mortar of our coexistence. In this section, I argue that austerity can be considered as a form of urbicide that (slowly) ruins this social infrastructure, whether a violence against housing, schools, parks, or other architectures of care. Geographic scholarship on violence reflects a dynamic field (e.g. Doel, 2018; Laurie and Shaw, 2018; Pain, 2014). I am interested in the violence against the built environment, or urbicide (Coward, 2006, 2007). An important conceptual parallel to urbicide is the term "geographic warfare" (Lacoste, 1973), understood as a form of ecological violence. This, as Yves Lacoste (1973) explained, was brutally manifest in the Vietnam War during the 1960s and 1970s, when the U.S. military used a range of weapons to destroy the Vietnamese rainforest-from Agent Orange to carpet bombing. "For the first time in history," writes Lacoste (1973: 2), "the modification and destruction of the geographical milieu (in both its physical and human aspects) is being used to obliterate those very geographical conditions which are indispensable for the lives of several million people" (see also Sloterdijk 2009).

Urbicide is similarly a type of geographical warfare. But unlike ecological violence, urbicide targets the built conditions of life. Urbicide is defined as violence against the city-the intentional destruction of civilian infrastructure. The devastation of the city of Sarajevo during the Bosnian War in the 1990 os popularized the term, if not the practice. Yet although urbicide is typically viewed as a "fast" and militaristic form of violence, it can also be a slow process of economic ruination (c.f. Till, 2012). In concert with scholars who have "slowed" the temporalities of violence (Nixon, 2011; Pain 2019), I argue below that urbicide can be understood as a slower form of violence, of letting the built environment die (Foucault, 2003). This provides a spatial framework for considering the worldly damage of austerity. In 
what follows, I document four definitions of urbicide to show the scope of the term. Yet there is an important caveat to urbicide: it can risk sidelining rural experiences of structural violence (see Nally, 2008).

The first meaning of urbicide is the most obvious: the wartime destruction of the built environment-what Hewitt (1983) termed "place annihilation." The bloody conflicts of the twentieth century are rife with examples of indiscriminate urbicide. Consider the aerial destruction of numerous cities in World War II. The second definition is the targeted ethnic cleansing of social infrastructure. This was violently laid bare in the ethno-nationalist conflicts of 1990 s Yugoslavia. The destruction of the Stari Most-a $16^{\text {th }}$ Century Ottoman bridge-by Croat forces on November 9, 1993, was an important flashpoint. The bridge had little strategic military value, but it embodied a rich Bosnian heritage (see Coward, 2006, 2007). Other examples include the urbicide of Phnom Penh during the Cambodian genocide (Tyner et al., 2014), the destruction of Lebanon (Fregonese, 2009; Ramadan, 2009), or the ongoing urbicide in the Palestinian territories. The bulldozing of the Jenin refugee camp, for example, was "a deliberate strategy to compel Palestinians to indefinite poverty" (Graham, 2002: 642). As Sari Hanafi (2013: 191) adds, "The Israeli settler-colonial project is not a genocidal project in a legal sense but a 'spacio-cidal' one. ... In the Palestinian-Israeli conflict, the Israeli target is the place." Or consider the sacking of Syrian civilian infrastructure in the civil war (Sharp, 2016).

The third meaning of urbicide is the destruction of what Coward (2006) terms existential heterogeneity. Heterogeneity-the condition of human difference and plurality (see Nancy, 2000)-is materialized and spaced by buildings. Buildings anchor our being-in-the-world. The urban thus provides the existential architecture by which our reality is registered-and affirmed-as coexistence. The urban landscape, in other words, materializes "coexistence in and through the shared spaces constituted by the built environment" (Coward, 2006: 431). This means that violence against buildings destroys the very conditions-or the "geographies of being" (Shaw and Laurie, 2018: 8)-for human difference and togetherness. This existential understanding of urbicide reverses "the 'anthropocentric bias' that accords more value to human life than to the "material' in, around, and through which that life is lived" (Coward, 2006: 420). The human condition is both nourished and harmed by the materials that surround it.

The final understanding of urbicide is an economic one, and closely resembles the spatial violence of austerity. In fact, the first definitions of urbicide in the 1960 s referred to such economic trauma. In a 1968 New York Times article, Ada Louise Huxtable penned Lessons in Urbicide to describe the violence of urban planning. In a similar vein, Marshall Berman used the term to describe the destruction of his South Bronx neighbourhood and displacement of 300,000 during construction of the World Trade Centers. "These stricken people belong to one of the largest shadow communities in the world, victims of a great crime without a name. Let us give it a name now: urbicide, the murder of a city" (Berman, 1987). Decades later, the destruction of New Orleans by Hurricane Katrina would materialize what Andrew Herscher (2006: 20) terms an "American variety of urbicide." This, he writes, is "a form of urban destruction that occurs through the confluence of racial segregation, structural impoverishment, urban disinvestment, and natural hazard."

\section{Slow Urbicide}

Urbicide can happen quickly-with the drop of a bomb, or the flames that engulfed Grenfell Tower, London, in 2017. But sometimes urbicide takes decades to bite, as public institutions, social housing, and common spaces gradually fall to rust and ruin. What, then, of slow urbicide-of a violence against the city that stretches to timescales that are difficult to detect? Rob Nixon (2011: 2) describes slow violence as "a violence that occurs gradually and out of sight, a violence of delayed destruction that is dispersed across time and space, an 
attritional violence that is typically not viewed as violence at all... but rather incremental and accretive, its calamitous repercussions playing out across a range of temporal scales.” The examples Nixon lists range from climate change to the radioactive aftermaths of wars. But what of economic violence? For example, in their research on the lived violences of austerity, Wilkinson and Ortega-Alcázar (2019: 156) write, "cuts to welfare are often experienced not as catastrophe, but as a slow and steady deterioration."

Slow urbicide does not wound bodies directly-but damages the social infrastructures of living, or "life structures" (Berlant, 2017). Consider Friedrich Engel's (2009) notion of social murder in The Condition of the Working Class in England. Capitalist living conditions in industrial England caused a "too early and an unnatural death." Engels documented the slum-like buildings of the poor: houses that were "ruinous, dirty, and miserable," (p.53) or overcrowded dwellings where "every nook and corner swarms with human beings" (p.111). The terrible housing conditions compounded the anxiety of working people, aggravating "the uncertainty of [their] existence" (p.113). What Engels famously termed social murder resulted from these deleterious living environments: a crime of "omission" rather than "commission" (p.107). Thus, we can appreciate how social murder not only takes place between bodies, but between bodies and the built environment-social murder is spatial murder.

Spatial murder requires that we slow down violence-to see it as a crime of letting the built environment die. This term, "letting die," is one I borrow from Michel Foucault (2003). He first wrote that sovereign power is felt most viscerally when it kills. But this power was later superseded by a government "power to 'make' live and 'let' die" (Foucault, 2003: 241). And this biopolitical power was directed at the environment. "This is, essentially, the urban problem" (Foucault, 2003: 244-5). The obverse of a biopolitical power is, therefore, letting die. Austerity's project of neglect, abandonment, and ruination encapsulates this environmental crime of omission, of slow urbicide. Yet in Sparke's (2017) account of biological sub-citizenship, he argues that the obverse of biopolitics is not letting die but a rejection into death-a slow violence of subordination, displacement, and exclusion that defies easy oppositions between biopolitics and necropolitics (Sparke 2017: 289).

Slow urbicide is not the direct murder by bombs, bullets, and shells-it is allowing the worldly artifice to fall to ruin, and this violence materializes complex textures and timescales. "Rather than harmed by a singular 'outside event'," explains Karen Till (2012: 6), "these forms of violence often work over a period of many years-often decades-and continue to structure current social and spatial relations." Slow urbicide is a violence against the material conditions of our coexistence: the buildings and social infrastructures by which the human condition flourishes or falls. Austerity can embed-even trap-people in toxic environments. Consider Rachel Pain's (2019) study of housing dispossession in the Durham coal-mining village of Horden. Pain documents how slow violence and trauma accumulates in place. Chronic urban trauma, she argues, is the worlding of violence, "encoded in the material, ecological and social fabric of certain places" (Pain, 2019: 388). In such spaces of impoverishment, residents live and feel trauma not simply as a fast, single event, but as a slow process of harm, despair, and barely-perceptible ennui, or world weariness (c.f. Wilkinson and Ortega-Alcázar, 2018). State housing policies infiltrate the background of being like biological contamination-seeping through time, space, bodies, and ecosystems. Slow urbicide, a sapping violence against the city's artifice, is felt-if even barely registeredas a worldly ennui.

\section{Ruined Worlds}

Austerity exacerbates "the endemic ruination of capitalism" (Dawdy, 2010: 763). I now consider the ruined geographies of urbicide-how buildings, bodies, and minds, "slip into ruination more gradually, sidelined by social or economic transitions, or incrementally 
abandoned (DeSilvey and Edensor, 2013: 466-467). World ruination is visible in contorted geographies, in "shells of abandoned factories, burned-out tenements, boarded-up schools, weedy lots, piles of concrete rubble, and faded commercial districts" (Dawdy, 2010: 762). And this spatial trauma is felt. People in austere worlds are forced to "live in and with the ruination of their workplaces, their unions, their towns, their environment, and their health" (High et al., 2018: 19-20). Consider housing in disrepair, damp and decay, rubbish and needles in yards and lanes, mould, the closing of libraries, illegal fly-tipping, derelict lots, the theft of roof tiles, pipes, and boilers, or arson, rats, asbestos, rows of vacant properties (see Pain, 2019), damaged roads, shut transport lines, as well as the sluggish erasure of public commons, such as parks, libraries, schools, nurseries, hospitals.

Phillip Alston's (2008) tour of the UK documented the dramatic shrinking of public worlds (Hitchen and Shaw 2019). The austere UK state halved the affordable housing budget between 2011 and 2015 compared to the previous four years. Around $£ 49.5$ billion has been taken from local councils between 2010 and 2017-or about $22 \%$ of their total funding (The Economist, 2017). That's a reduction of $45 \%$ in housing budgets and close to $40 \%$ of transport budgets. Indeed, Treasury support to councils will fall to $£ 3.2$ billion in 20192020, down from $£ 7.2$ billion in 2016-17. Over 478 libraries have closed in England, Wales, and Scotland since 2010 (Harris, 2017). A third of "Sure Start" children's centres-designed for some of the most disadvantaged children-have closed under the Conservatives (Walker, 2017). Between 2012 and 2016, 603 youth centres were closed (UNISON, 2016). These examples demonstrate how austerity bites deeply into the lived spaces of human coexistence (Hitchen, 2016, 2019) - as well as the wider enclosure of public space across the UK (Christophers, 2018). In the U.S, consider the well-documented case of lead poisoning in Flint's water supply, or the violent inequities of drinking water infrastructure-what Dietz and Meehan (2019) term "plumbing poverty."

Accordingly, it's important to bear witness-and document-austerity's lived archeology and lived process of ruination. Ruins are contested political matters (Gordillo, 2014; Martin, 2014). How, then, does the slow urbicide of austerity, "persist in their material debris, in ruined landscapes and through the social ruination of people's lives" (Stoler, 2008: 194)? Scholarship on ruins has examined the injustices and political economies that produce spaces of decay (Dawdy, 2010; DeSilvey and Edensor, 2013; High et al., 2018; Mah 2010). Ruin can be understood as both a noun and a "vibrantly violent verb" (Stoler 2008: 194). As a noun, ruin refers to a state of physical destruction, and as a verb, ruin is the process of reducing places to a state of collapse. As Ann Stoler explains:

"Ruination is an act perpetrated, a condition to which one is subject, and a cause of loss. These three senses may overlap in effect but they are not the same. Each has its own temporality. Each identifies different durations and moments of exposure to a range of violences and degradation that may be immediate or delayed, subcutaneous or visible, prolonged or instant, diffuse or direct" (Stoler, 2008: 195-196)

Austerity has left a trail of living fossils that disclose its urbicidal harm. Accordingly, we must ask $w h o$ is forced to live in ruin? Housing is an important site to explore this question, for housing is intimately worlded by the violent conditions of austerity. Since 2010 in the UK, the funding available for supporting vulnerable people with their housing has been cut by $59 \%$ in real terms (National Audit Office, 2017). This leads to a range of problems-since housing has long been identified as a key determinant of physical and psychological wellbeing (Hiscock et al., 2001; Renalds et al., 2010; Shaw, 2004). People living in overcrowded, substandard or insecure homes are more likely to experience health issues. For this reason, geography has a rich history of lodging housing at the centre of class struggles and social justice (Hodkinson and Robbins, 2013; Gray, 2018). 
Housing can be studied from two analytical perspectives. First, it is quite clearly a physical architecture: a material structure that shelters humanity from the rain, the wind, and the cold, enclosing the human body. This physicalist understanding was the focus of early housing studies, which documented how physical attributes of housing (such as mould, vermin, and damp) were determinants of health (see Clair et al. 2016; Shaw, 2004). The epidemiological link between housing and health has been well documented: cold housing can lead to respiratory infection and heart disease, overcrowding can cause emotional and developmental problems, and poor building design and vermin infestations are associated with a range of mental health problems (Pevalin et al., 2008).

Second, housing can be studied as an existential architecture that orients our social relationships (Cohen et al. 2003) and being-in-the-world (Coward, 2006). Housing constellates how spatial beings are able to dwell, interact, and flourish in the worldgathering people, objects, animals, machines, moods, sensations, emotions, thoughts, and practices. As Mary Shaw (2004: 408) argues, "As well as comprising shelter from the elements, housing can provide refuge in a social and psychological sense-a home can confer safety and privacy." Housing thus orients how we experience our being-there, our place in the world. To have a place in the world is not a relationship of ownership but to feel alive, secure, and belonging, in one's space. In other words, housing is continually experienced through a spectrum of sensations ranging from existential belonging to alienation (Hiscock et al., 2001).

Housing discloses what Ella Harris et al. (2018) term a "structure of feeling." Housing crises-and urban precarity-are lived, internalized, and felt. "Residents' daily lives are governed by atmospheres of anxiety in the housing crisis as structure of feeling, as well by their own personal uncertainties, worries and crises" (Harris et al. 2018). Austerity's world ruination, in short, generates a range of spatial maladies. In one study, Cohen et al. (2003) found that "neighborhood physical deterioration, as measured by the presence of boardedup vacant housing units, was associated with premature mortality from all causes"-even after controlling for socioeconomic variables. And as Macintyre et al. (2003) documented, housing temperature, damp, noise, and state of disrepair, all affected levels of anxiety and depression. Austerity's worldings and woundings have a direct effect on our existence-the explicit focus of the next section.

\section{Slipping Away from the World: Unreality}

In this section, I provide an explicitly existential understanding of slow urbicide. How does it feel to be in the there? Austerity worlds people into violent spaces that are intimately felt. The built environment can provide existential shelter for human beings, threading our existence into the flesh of the world. But it can just as easily produce a negative experience of being-there. "When places are physically demolished", writes Till (2012: 10), "an individual's personal and intrasubjective emotional ecosystems become damaged." In other words, the world can nurture, secure, and affirm our being-there-but it can also stand against its inhabitants in relations of indifference, alienation, or even hostility. Poor quality housing can drastically affect one's mental and physical health (Cohen et al. 2003, Macintyre et al. (2003) and sense of worldly belonging. Consider how, in England, there was a 165 percent increase in antidepressants between 1998 and 2012. Crucially, this was acute in "areas with worse living environments" (Spence et al., 2014: 27).

Austerity can ruin the there of our being-there. By damaging the built environment, austerity gnaws at the human condition, particularly those already-excluded communities. This is an important legacy of urbicide, and one whose "ecologies of the aftermath" can be felt for decades (Pain, 2019). Arendt, to recall, argued for the importance of the world-of the social infrastructures that entangle us - to the human condition. As she put it, "the objectivity of the world-its object- or thing-character-and the human condition supplement each other" 
(Arendt, 2013: 9). The idea of world undermines the notion of a sealed individual, and for this reason, the ruins of austerity are continually interiorized. Sometimes this process is physical, as when asbestos or other noxious substances are inhaled by the lungs. Other times, ruination is a process of psychological interiorization, as with the pronounced anxiety of living in dilapidated buildings (Shaw, 2004: 409).

The built environment thus draws humans together in spaces of "ontological security" (Giddens, 1990) and heterogeneity (Coward, 2006)-anchoring, or materializing, our existence as coexistence. RD Laing described ontological security as the psychological state of coherence: people who "experience [their] own being as real, alive, whole... as a continuum in time; as having an inner consistency, substantiality, genuineness, and worth" (1990: 25). Basic to this feeling of ontological security is a sense of reliability in the world. As Anthony Giddens (1990) would later emphasize, this is a feeling of existential security: "The confidence that most human beings have in the continuity of their self-identity and in the constancy of their social and material environments" (Giddens, 1990: 92 my emphasis). Accordingly, ontological security and the material environment are symbiotic. If, as Arendt (2013: 96) argues, human reality rests on "things more permanent than the activity by which they were produced," then any erosion of these social infrastructures impacts our sense of self and existential wellbeing.

The state of the built environment is crucial for nurturing, or harming, ontological security (Hiscock et al., 2002; see also Botterill et al., 2017). As worlds are ruined, as austerity shrinks the spaces in which we can dwell and obtain meaning, "anxieties come flooding in" (Giddens, 1990: 98). The resulting ontologically insecure individual may experience an "inner deadness" or "lifelessness" (Giddens, 1990: 53-54). At is most extreme, austerity can contribute to an existential loss of self. When the world is so ruined that it no longer nurtures one's existence, when the world is no longer inscribed by one's existence, there is the ever-present possibility of de-realization: the sensation of being more unreal than real, of losing the self.

RD Laing termed this a state of ontological insecurity. Ontological insecurity names this feeling of being "more unreal than real" (Laing, 1990: 26), "a precarious and threatened sense of existence.... battle somehow to save the "self' from slipping out of existence" (McGeachan, 2014: 96). As spatial creatures who are always "with," the urbicidal stripping of the world denies our "withness." For who are we, if the world does not recognize us? Here, recognition is an existential encounter-a sharing, an affirmative dwelling, between the individual and world.

Urbicide, to recall Coward (2006: 434), aims "at establishing the fiction of a being-withoutothers." Amongst the ruins of austerity, it becomes hard to find a place in the world. Arendt wrote that the world provides a "space of appearance"-where our existence as coexistence is validated. Being seen and heard by others in the commons constitutes our reality. "The presence of others who see what we see and hear what we hear assures us of the reality of the world and ourselves" (Arendt, 2013: 50). This is the vital role played by worlds. World ruination deprives us of the joy of recognition-of being seen, heard, and felt by others. To be real rather than unreal, to be ontologically secure rather than insecure, requires the mutuality of others. To deprive human beings of a dignified world is to deny a fundament of the human condition.

World alienation is Arendt's (2013) term for this loss of an intersubjective, plural world of experience, by which we establish our identity and reality. Austerity's slow violence can ruin the spaces of coexistence, leaving behind a panorama of isolated, alienated, and unreal figures. In 2018, the Conservative government appointed the world's first "minister for loneliness" to tackle soaring rates of loneliness. Perhaps this minister will reverse the closure of $41 \%$ of adult day centres under the government's watch-since these spaces are a lifeline 
for the elderly and vulnerable (Robertson, 2018; see Stenning and Hall, 2018). Chronic poverty, infrastructural damage, and a lack of decent housing, all contribute to the spatial trauma of unreality-of a fundamental dis-placement in the world.

\section{Working for Dignified Worlds}

As our place in the world is ruined, and our spatial attachments crumble and crack, we nonetheless gain a precarious freedom to begin anew. Living amidst the rubble can-and does-prompt a revaluation of the worlds we do want (Mah, 2010: 398). Even within the most blasted landscapes of austerity, "We can still catch the scent of the latent commons" (Tsing, 2015: 282). In this penultimate section, I want to discuss the ethical imperative to work for the world. So much of our daily activity is not directed at the world. It is either indifferent, or hostile, to the social infrastructures of our coexistence. Many jobs gift nothing to the world-but are instead structured by the pulses of capital accumulation. Accordingly, work must be reclaimed and reworlded from austere worlds. The task is to build, craft, engineer, sew, cook, fix, plug, plumb, and grow anew (see Huron, 2018; Roelvink, 2016). The survival of dignified worlds-rather than austere worlds-demands us to work for better housing, better parks, better social infrastructure, better transport, better cities.

The typical understanding of "work" is servile and overdetermined by capitalist realism (Fisher, 2009). Accordingly, we need to be careful with how we use the term work-since its definition impacts how we imagine-and build-worlds beyond austerity. I thus find much value in Arendt's (2013) analytic distinction between the human activities of labor and work. Laboring is the (capitalist) production of perishable commodities for consumption. Work, on the other hand, is what Arendt defines as a world-building craft, which creates durable objects and infrastructures to nourish, strengthen, and maintain public worlds. The sum total of these objects forms what Arendt (2013: 136) termed the artifice: the worldly infrastructure that shelters us. Without this infrastructure, we stand exposed to the uncaring cycles of commodified life, "the deathless everlastingness of the human as of all other species" (Arendt, 2013: 97). Without work-the condition of worldliness-what remains is the circulation of capital and its austere discontents.

Of course, a strict distinction between labor and work misses their messy overlap (as well as the role of the welfare state). Nonetheless, by holding the distinction, I do want to accentuate the importance of working-caring-for the world as an ethical imperative. This is the investment of our energy into the architectures of coexistence: an act of generosity that makes public space liveable and dignified. For example, Till describes place-based caring as "a type of engagement with the world that is both rational and affective (Till, 2012: 103, my emphasis). Place-based caring includes neighbourhood gatherings, community potlucks, organizing political protests. We can also add repainting old houses, picking up trash in streets, installing renewable energy supplies, reclaiming abandoned lots, weeding public parks, volunteering at community centres, or growing urban gardens. Such worldliness lodges social reproduction (Meehan and Strauss, 2015) into our understanding of political being-in-the world. But this type of care can, and is, easily coopted by capital (as with terms like resilience). Of course: this is not always the case. Important examples from history, such as the survival programs of the Black Panthers (Hilliard, 2008), demonstrate how parallel institutions, mutual aid, and autonomous sites can function as explicitly anti-capital, antiracist, and multi-scalar spaces (Heynen, 2009).

By working for the world, we rematerialize the possibilities for (existential) recognition and mutuality. Fundamentally, work enables people to inscribe their existence into the flesh of the world-one brick, one plant, one craft at a time. Work creates novel foldings of matter and thought and constructs new architectures of cobeing. "Building is the productive activity through which human beings make a place for themselves in the world" (Malpas, 2008: 177). There is so much anger, sadness, and despair, from having so little invested-so little 
inscribed-in our surroundings. The austere worlds that many of us labour in provide neither a "space of exteriorization" nor of nourishment: they are wounded, forgotten, dilapidated-or else indifferent to our existence. When one works for the world, when one fabricates, one brings into the there something that didn't exist before-it is a moment of self-realization and of new potentials for coexistence. Work, writes Andre Gorz (1999: 2), is "a process of exteriorization by which subjects achieve self-realization by inscribing themselves upon the objective materiality of what they create or produce." Working for the world strives to leave it a more caring-and recognizable-place.

\section{Conclusion: The Right to the World}

In this paper, I've argued that austerity is a process of slow urbicide that ruins the world. I've been inspired by approaches that emphasize the lived experiences of austerity (Hall, 2018; Hitchen, 2016), and guided by understandings of how violence and trauma are spatialized (Pain, 2019; Stenning, 2018; Till, 2012). My key contribution has been to forefront the concept of world in how we diagnose, confront, and build beyond austerity. We flourish, or we suffer, because of our existence in the there. Our coexistence is built alongside houses, roads, schools, libraries, parks, pipes, and other structures of life (Berlant, 2016). Urbicide strips us of our place in the world. Nowhere is this dis-placement more obvious than in wartorn cities. "Citizens lose voice and agency, are alienated from urban spaces, experience restrictions on ways of saying and being, live with death as they eat and sleep" (Stanley 2017: 13). But the urbicidal violence of austerity can produce parallel experiences of world alienation on slower timescales. For this reason, I want to end the paper by insisting on the right to the world as a political and ethical rallying call. This is the right to construct existential spaces of belonging and exteriorization.

In 1968, Henri Lefebvre called for a right to the city: a right to autonomous, publicly owned urban spaces beyond capitalism. The right to the city involves residents uniting to manage the production of urban space for themselves, thereby "taking control of the conditions of their own existence" (Purcell, 2013: 150). Or as David Harvey (2008: 23) puts it, this "is a right to change ourselves by changing the city." But what if we consider the conditions of our existence beyond the city? What if we imagine a right to the world: a right to access, build, and use collective social infrastructures? Joseph Nevins (2017) defines the right to the world as a right to free movement across the planet and an equal share in its resources. What I want to emphasize is the right to appear, to dwell, and to be recognized, in the world. Berlant (2016: 409) argues, "Mid-twentieth century forms of expansive world building toward the good life have little or unreliable traction." But world building need not be expansive to make a difference. The right to the world is performed in abandoned buildings, community and school gardens, volunteer centres, temporary and permanent autonomous zones, free schools, pirate radio stations, squats, collectives, communes, LETs, and other urban commons (see Huron, 2018). All are important sites for enacting-and working for-a brand new there.

The right to the world cannot be contained to a single geography-so long as we keep working for it. One of the most insidious traits of austerity is that it robs people of their simple belief in the world. For who can believe in a world that no longer believes in them? Our task-as geographers, and as neighbours of the there-is to learn how to care for the world, despite its many horrors. "Education", writes Hannah Arendt (2006: 193), "is the point at which we decide whether we love the world enough to assume responsibility for it, and by the same token save it from... ruin."

\section{Acknowledgements}


I would like to thank Natalie Oswin and three anonymous reviewers for their supportive comments on previous versions of this paper.

\section{References}

Alston, P. (2018). Statement on Visit to the United Kingdom.

https://www.ohchr.org/Documents/Issues/Poverty/EOM GB 16Nov2018.pdf (accessed 9 December 2018).

Arendt, H. (1981). The Life of the Mind. London: Harcourt

Arendt, H. (2006). Crisis in Education. In: Between Past and Future. New York: Penguin, 170-193.

Arendt, H. (2013). The Human Condition 2nd ed. Chicago: University of Chicago Press.

Bambra, C. \& Garthwaite, K. (2015). Austerity, welfare reform and the English health divide. Area 47(3), 341-343

Berlant, L. (2011). Cruel Optimism. Durham, N.C.: Duke University Press.

Berlant, L. (2016). The commons: infrastructures for troubling times. Environment and Planning D: Society and Space 34(3): 393-419.

Berman, M. (1987). Among the Ruins. New internationalist, 178. Available at: https://newint.org/features/1987/12/05/among (accessed June 1 2018).

Botterill, K., Hopkins, P., Sanghera G. S. (2017). Young people's everyday securities: preemptive and pro-active strategies towards ontological security in Scotland. Social and Cultural Geography, Online First

https://www.tandfonline.com/doi/full/10.1080/14649365.2017.1346197

Butler, J. (2015). Notes Towards a Performative Theory of Assembly, Cambridge, Mass.: Harvard University Press.

Butler, P. (2017). Levels of child hunger and deprivation in UK among highest of rich nations. The Guardian, https://www.theguardian.com/society/2017/jun/15/levels-of-childhunger-and-deprivation-in-uk-among-highest-of-rich-nations

Bambra, C. and Garthwaite, K. (2015). Austerity, welfare reform and the English health divide. Area 47(3): 341-343.

British Medical Association. (2016). Health in All Policies: Health, Austerity, and Welfare Reform.

Christophers, B. (2018). The New Enclosure: The Appropriation of Public Land in Neoliberal Britain. London: Verso.

Clair, A, Reeves, A., Loopstra, R., McKee, M., Dorling, D., and Stuckler, D. (2016). The impact of the housing crisis on self-reported health in Europe: multilevel longitudinal modelling of 27 EU Countries." European Journal of Public Health 26(5): 788-93.

Cohen, D. A, Mason, K., Bedimo, A. Scribner, R., Basolo, V., and Farley, T. A. (2003). Neighborhood physical conditions and health. American Journal of Public Health 93(3): 467-71. 
Coward, M. (2006). Against anthropocentrism: the destruction of the built environment as a distinct form of political violence. Review of International Studies, 32(3): pp.419-437.

Coward, M. (2007). 'Urbicide' reconsidered. Theory and Event, 1O(2).

Dawdy, S. L. (2010) Clockpunk anthropology and the ruins of modernity. Current Anthropology 51(6): 761-793.

Department for Communities and Local Government. (2017). Local authority housing statistics: year ending March 2016, England. Available at:

https://assets.publishing.service.gov.uk/government/uploads/system/uploads/attachment data/file/582793/Local Authority Housing Statistics England year ending March 20 16.pdf (accessed 1 June 2018)

Derickson, K. D. (2017). Urban geography II: urban geography in the Age of Ferguson. Progress in Human Geography, 41(2): 230-244.

DeSilvey, C. \& Edensor, T. (2013). Reckoning with ruins. Progress in Human Geography, 37(4): 465-485.

Doel, M. (20108). Geographies of Violence: Killing Space, Killing Time. London: Sage.

The Equality Trust. (2017). The scale of economic inequality in the UK. Available at:

https://www.equalitytrust.org.uk/scale-economic-inequality-uk (accessed 1 June 2018)

The Economist. (2017). Britain's local councils face financial crisis. Available at:

https://www.economist.com/britain/2017/01/28/britains-local-councils-face-financial-

crisisv (accessed June 2018)

Engels, F. (2009). The Condition of the Working Class in England. Oxford: Oxford University Press.

Foucault, M. (2003). "Society Must Be Defended": Lectures at the Collège de France, 19751976. New York: Penguin.

Giddens, A. (1990). The Consequences of Modernity. Cambridge: Polity Press.

Gordillo, G. (2014). Rubble: The Afterlife of Destruction. Durham: Duke University Press.

Graham, S. (2002). Bulldozers and bombs: the latest Palestinian-Israeli conflict as asymmetric urbicide. Antipode, 34(4): 642-649.

Gray, N. (2018). Eds. Rent and its Discontents: A Century of Housing Struggle. London: Rowan \& Littlefield International.

Hall, S.M. (2017). Personal, relational and intimate geographies of austerity: ethical and empirical considerations. Area 49(3): 303-310.

Hall, S. M. (2018). Everyday austerity: Towards relational geographies of family, friendship and intimacy. Progress in Human Geography. Online First:

https://journals.sagepub.com/doi/10.1177/0309132518796280 
Hamnett, C. (2014). Shrinking the welfare state: the structure, geography and impact of British government benefit cuts. Transactions of the Institute of British Geographers 39(4): 490-503.

Hanafi, S. (2013). Explaining spacio-cide in the Palestinian territory: Colonization, separation, and state of exception. Current Sociology 61(2): 190-205.

Harris, J. (2017). The Tories are saving libraries - and closing the book on social mobility. The Guardian, available at:

https://www.theguardian.com/commentisfree/2017/dec/15/tories-libraries-social-mobilityconservative (accessed 1 June 2018).

Harris, E., Nowicki, M., and Brickell, K. (2018). On-edge in the impasse: inhabiting the housing crisis as structure-of-feeling." Online First. Geoforum, doi:10.1016/j.geoforum.2018.09.001

Harvey, D. (2014). Seventeen Contradictions and the End of Capitalism. London: Profile Books.

Herscher, A. (2006). American urbicide. Journal of Architectural Education, 60(1): 18-20.

Hewitt, K. (1983). Place annihilation: area bombing and the fate of urban places. Annals of the Association of American Geographers 73(2): 257-284.

Heynen, N. (2009). Bending the bars of empire from every ghetto for survival: The black panther party's radical antihunger politics of social reproduction and scale. Annals of the Association of American Geographers 99(2): 406-422.

High, S., Mackinnon, L. and Perchard, A. (eds) (2017). The Deindustrialized World: Confronting Ruination in Postindustrial Places. Vancouver: University of British Columbia Press.

Hilliard, D. (ed) (2008). The Black Panther Party: Service to the People Programs, Albuquerque: University of New Mexico Press.

Hiscock, R., Kearns, A., MacIntyre, S., and Ellaway, A. (2001). Ontological security and psycho-social benefits from the home: qualitative evidence on issues of renure. Housing, Theory and Society 18: 50-66

Hitchen, E. (2016). Living and feeling the austere. New Formations 87: 102-118.

Hitchen, E. (2019). The affective life of austerity: uncanny atmospheres and paranoid temporalities. Social and Cultural Geography, https://doi.org/10.1080/14649365.2019.1574884

Hodkinson, S. (2012). The new urban enclosures. City 16(5): 500-518.

Hodkinson, S. and Robbins, G. (2013). The return of class war conservatism? Housing under the UK Coalition Government. Critical Social Policy 33(1): 57-77.

Huron, A. (2018). Carving out the Commons: Tenant Organizing and Housing in Washington, D.C. Minneapolis: University of Minnesota Press. 
Krugman, P. (2015). The austerity delusion. The Guardian, available at: https://www.theguardian.com/business/ng-interactive/2015/apr/29/the-austerity-delusion (accessed June 1 2018).

Lacoste, Y. (1973). An illustration of geographical warfare: bombing of the dikes on The Red River, North Vietnam. Antipode 5(2): 1-13.

Laing, R.D. (1965). The Divided Self. London: Penguin Books.

Lambie-Mumford, H. \& Green, M.A. (2017). Austerity, welfare reform and the rising use of food banks by children in England and Wales. Area 49(3): 273-279.

Laurie, E. W. and Shaw, I.G.R. (2018). Violent conditions: the injustices of being. Political Geography 65: 8-16.

Laing, R. D. (1969). The Divided Self. London: Penguin Books.

Lefebvre, H. (1991). The Production of Space. Translated by D. Nicholson-Smith. The Production of Space. Oxford: Blackwell.

Mah, A. (2010). Memory, uncertainty and industrial ruination: Walker riverside, Newcastle upon Tyne. International Journal of Urban and Regional Research 34(2): 398-413.

Malpas, J. (2008). Heidegger's Topology: Being, Place, World. Cambridge, Mass.: The MIT Press.

Martin, D. (2014). Introduction: Towards a political understanding of new ruins. International Journal of Urban and Regional Research, 38(3): 1037-1046.

McCormack, D.P. (2017). The circumstances of post-phenomenological life worlds. Transactions of the Institute of British Geographers 42(1): 2-13.

McGeachan, C. (2014). 'Worlding' psychoanalytic insights: unpicking R.D. Laing's geographies. In: Kingsbury, P. and Pile, S. (eds.) Psychoanalytic Geographies. Ashgate: Farnham.

McIntyre, M., \& Nast, H. J. (2011). Bio(necro)polis: Marx, Surplus Populations, and the Spatial Dialectics of Reproduction and "Race." Antipode, 43(5), 1465-1488.

Macintyre S, Ellaway A, Hiscock R, Kearns A, Der G, Mackay L. 2003. What features of the home and the area might help to explain observed relationships be- tween housing tenure and health? Evidence from the west of Scotland. Health Place 9:207-18

Meehan, K., \& Strauss, K. (eds.). (2015). Precarious Worlds: Contested Geographies of Social Reproduction. Athens: University of Georgia Press.

McKittrick, K. (2011) On plantations, prisons, and a black sense of place. Social \& Cultural Geography 12(8): 947-963.

Nally, D. (2008). "That Coming Storm": The Irish Poor Law, Colonial Biopolitics, and the Great Famine. Annals of the Association of American Geographers, 98(3), 714-741.

Peck, J. (2012). Austerity urbanism. City 16(6): 626-655. 
Pulido, L. (2017). Geographies of race and ethnicity II: Environmental racism, racial capitalism and state-sanctioned violence. Progress in Human Geography 41(4): 524-533

Neocleous, M. (2013). Resisting resilience. Radical Philosophy 178 (March/April). Available at: https://www.radicalphilosophy.com/commentary/resisting-resilience (accessed June 1 2018).

Newman, J. (2013). Landscapes of antagonism: Local governance, neoliberalism and austerity. Urban Studies 51(15): 3290-3305.

Nevins, J. (2017). The right to the world. Antipode 49(5): 1349-67.

Nixon, R. (2011). Slow Violence and the Environmentalism of the Poor. Harvard University Press.

Pain, R. (2014). Everyday terrorism: connecting domestic violence and global terrorism. Progress in Human Geography 38(4): 531-50.

Pain, R. (2019). Chronic urban trauma: the slow violence of housing dispossession. Urban Studies, 56(2): 285-400.

Robinson, C. J. (1983). Black Marxism: The Making of the Black Radical Tradition. Chapel Hill: The University of North Carolina Press.

Pearce, J. (2013). Financial crisis, austerity policies, and geographical inequalities in health. Environment and Planning A, 45(9): 2030-2045.

Pevalin, D. J., Taylor, M. P., \& Todd, J. (2008). The dynamics of unhealthy housing in the UK: A panel data analysis. Housing Studies, 23(5), 679-695.

Roelvink, G. (2016). Building Dignified Worlds: Geographies of Collective Action. Minneapolis: University of Minnesota Press.

Sharp, D. (2016). Urbicide and the Arrangement of Violence in Syria. In D. Sharp \& C. Panetta (Eds.) Beyond the Square: Urbanism and the Arab Uprisings. Terreform (pp. 118141).

Shaw, M. (2004). Housing and public health. Annual Review of Public Health 25: 397-418.

Siddique, H. (2017). Health cuts most likely cause of major rise in mortality, study claims. The Guardian, available at: https://www.theguardian.com/society/2017/feb/17/healthcuts-most-likely-cause-major-rise-mortality-study-claims (last accessed June 12018 ).

Slater, T. (2014). The Myth of "Broken Britain": Welfare Reform and the Production of Ignorance. Antipode 46(4): 948-969.

Sloterdijk, P. (2009). Terror from the Air. Translated by Amy Patton and Steve Corcoran. Los Angeles: Semiotext(e).

Sparke, M. (2017). Austerity and the embodiment of neoliberalism as ill-health: Towards a theory of biological sub-citizenship. Social Science and Medicine 187: 287-295.

Spence, R., Roberts, A., Ariti, C., \& Bardsley, M. (2014). Focus On: Antidepressant prescribing. Trends in the prescribing of antidepressants in primary care. The Health Foundation and the Nuffield Trust. 
Stenning, A. (2018). Feeling the squeeze: towards a psychosocial geography of austerity in low-to-middle income families." Geoforum, Online First:

doi:10.1016/j.geoforum.2018.09.035

Stenning, A. and Hall, S. M. (2018). On the frontline: loneliness and the politics of austerity. Discover Society. https://discoversociety.org/2018/11/06/on-the-frontline-loneliness-andthe-politics-of-austerity/ (last accessed April 2 2019)

Stoler, A.L. (2008). Imperial debris: reflections on ruins and ruination. Cultural Anthropology 23(2): 191-219.

Till, K. E. (2012). Wounded cities: Memory-work and a place-based ethics of care. Political Geography 31(1): 3-14.

The Trussell Trust. (2018). End of year stats. https://www.trusselltrust.org/news-andblog/latest-stats/end-year-stats/ (last accessed April 3 2019)

Tyler, I. (2013). The riots of the underclass. Sociological Research Online.

http://www.socresonline.org.uk/18/4/6.html (last accessed December 12 2018)

Tyner, J. A. (2016). Population Geography III: Precarity, dead peasants, and truncated life. Progress in Human Geography 40(2), 275-289.

Tyner, J. A., Henkin, S., Sirik, S., \& Kimsroy, S. (2014). Phnom Penh during the Cambodian genocide: a case of selective urbicide. Environment and Planning A 46(8): 1873-1891.

Tsing, A.L. (2015). The Mushroom at the End of the World: On the Possibility of Life in Capitalist Ruins. Princeton: Princeton University Press.

UNISON (2016). A Future at Risk: Cuts in Youth Services. Available at: https://www.unison.org.uk/content/uploads/2016/08/23996.pdf (accessed June 1 2018)

Wacquant, L., Slater, T., \& Pereira, V. B. (2014). Territorial stigmatization in action. Environment and Planning A 46(6): 1270-1280.

Walker, M. 2017 A third of Sure Start children's centers in England lost, says Labour. The Guardian, available at: https://www.theguardian.com/society/2017/apr/05/sure-startchildrens-centres-cuts-labour (accessed June 12018 )

Wilkinson, E, and Ortega-Alcázar, I. (201). The right to be weary? Endurance and exhaustion in austere times. Transactions of the Institute of British Geographers, 44:155-167.

\footnotetext{
i Heidegger's work, and legacy, is contaminated by his anti-Semitism and membership of the Nazi party during the 1930 s.
} 